\title{
PENERAPAN FULL DAY SCHOOL DI SMA NEGERI 1 SINGARAJA (LATAR BELAKANG PENERAPAN DAN PENGARUHNYA TERHADAP PRESTASI BELAJAR SOSIOLOGI DI KELAS XI IIS)
}

\author{
Ema Maulidya Bawazir ${ }^{1}$, Dr. I Wayan Mudana, M.Si ${ }^{2}$, Dr. Luh Putu Sendratari, M.Hum ${ }^{3}$ \\ Program Studi Pendidikan Sosiologi \\ Jurusan Sejarah Sosiologi dan Perpustakaan \\ Universitas Pendidikan Ganesha \\ Singaraja, 2020 \\ e-mail: \{emabawazir@gmail.com, mudanawayan60@gmail.com, \\ lpsendratari@gmail.com.
}

\begin{abstract}
Abstrak
Penelitian ini bertujuan untuk mengetahui (1) Penerapan Full Day School di Sekolah Menengah Atas (SMA) Negeri 1 Singaraja, (2) Pengaruh Full Day School terhadap prestasi belajar sosiologi kelas XII IIS. Konsep yang digunakan untuk menjawab rumusan masalah yaitu Penerapan dan Pengaruh Full Day School, prestasi belajar. dengan langkah penentuan informan yang terdiri dari siswa kelas XI IIS yang menerapkan Full Day School, Kepala Sekolah, Guru sosiologi SMA Negeri 1 Singaraja. Metode yang digunakan dalam penelitian ini ialah metode kualitatif.Teknik pengumpulan data yang digunakan yaitu, teknik observasi langsung, wawancara, dan studi dokumen, angket atau kuesioner. Hasil penelitian menunjukkan bahwa (1) Penerapan Full Day School di SMA Negeri 1 Singaraja telah berjalan dengan baik, dengan segala penunjang yang ada di SMA Negeri 1 Singaraja dan dari hasil data penyebaran kuesioner ke siswa $70 \%$ siswa memberikan respon positif terhadap penerapan ini dengan menyetujui penerapan lima hari sekolah ini. Penerapan lima hari sekolah ini juga berpengaruh terhadap prestasi belajar anak dan pengaruh nya cukup signifikan. Jika dilihat dari hasil pengamatan dan nilai raport siswa kelas XI IIS, Namun prestasi belajar siswa tidak hanya dilihat dari faktor dari dalam diri individu saja melainkan faktor dari luar individu, yaitu terdiri dari faktor lingkungan dan faktor instrumental. Dan Full Day School termasuk ke dalam faktor dari luar karena berupa kebijakan yang diterapkan oleh pemerintah.
\end{abstract}

Kata Kunci: Lima Hari Sekolah, Kebijakan Pemerintah, Prestasi, Belajar, Sosiologi.

\begin{abstract}
This study aims to determine (1) Implementation of Full Day School in State Senior High School 1 Singaraja, (2) Effect of Full Day School on the learning achievement of class XII IIS sociology. The concept used to answer the problem formulation is the Implementation and Effect of Full Day School, learning achievement. with the step of determining the informants consisting of students of class XI IIS who implement Full Day School, School Principal, Sociology teacher at SMA Negeri 1 Singaraja. The method used in this study is a qualitative method. Data collection techniques used are, direct observation techniques, interviews, and study of documents, questionnaires or questionnaires. The results showed that (1) The implementation of Full Day School in SMA Negeri 1 Singaraja had been going well, with all the supports in SMA Negeri 1 Singaraja and from the results of questionnaire distribution to students $70 \%$ of students gave a positive response to this application by agreeing the application of these five days of school. The application of these five school days also influences children's learning achievement and their influence is quite significant. If seen from the observations and report cards grades of class XI IIS students, however student achievement is not only seen from factors within the individual alone but factors from outside the individual, which consists of environmental factors and instrumental factors. And Full Day School is included in external factors because it is a policy implemented by the government.
\end{abstract}

Keywords : Full Day School, Five Days of School, Government Policy, Achievement, Study, Sociology 


\section{PENDAHULUAN}

Pendidikan merupakan sektor yang sangat penting untuk meningkatkan harkat dan martabat bangsa indonesia. Beberapa usaha telah dilakukan oleh para pengelola pendidikan untuk memperoleh suatu produk atau hasil pendidikan yang berkualitas, yaitu dengan cara melakukan mutu pendidikan sekolah secara bertahap dan terus menerus. Sehingga tidak dapat dipungkiri bahwa pendidikan sekolah di Indonesia bersifat dinamis artinya selalu melakukan berbagai perubahan yang menuju ke arah yang lebih baik. Pemerintah menetapkan kebijakan terkait Full Day School, Salah satu potret adanya upaya pemerintah dalam mewujudkan hal tersebut tercermin dari kebijakan pemerintah yang di atur oleh Peraturan Kementerian Pendidikan dan Kebudayaan (Permendikbud) Nomor 23 tahun 2017 tentang hari sekolah mulai tahun ajaran $2017 \backslash 2018$ sekolah berlangsung Senin s.d Jum'at (lima hari sekolah) Sabtu libur total dengan jam sekolah menjadi delapan jam belajar setiap harinya, tetapi tidak semua sekolah yang ada di Indonesia menerapkan kebijakan ini. Dimana arti pendidikan disini bukan hanya mentransfer knowledge (pengetahuan) tetapi juga mengubah tingkah laku setiap anak untuk menjadi anak yang berkarakter.

Meningkatkan kualitas pendidikan, tentunya Indonesia mempunyai cara khusus sebagai upaya peningkatan pendidikan menuju pada tujuan pendidikan, yang sudah tertera pada Undang- Undang (UUD) sistem pendidikan nasional Nomor 20 tahun 2003 pasal 3. Penerapan lima hari sekolah telah diterapkan oleh beberapa sekolah negeri di kota Singaraja, salah satunya ialah Sekolah Menengah Atas (SMA) Negeri 1 Singaraja. Sekolah Menengah Atas (SMA) Negeri 1 Singaraja merupakan salah satu sekolah favorit dan tertua di kota Singaraja serta menjadi sekolah rujukan pertama di Buleleng, sekolah lain yang telah menerapkan akan mengacu pada penerapan Full Day School di Sekolah tersebut.Tentu sekolah memiliki tujuan dengan diadakannya program tersebut sejak lama di sekolah, tidak hanya prestasi akademik dan non akademik tentu pihak sekolah juga mengedepankan ahklak setiap siswa-siswi nya agar menjadi insan yang bertaqwa dan berkarakter. Hal ini tentu membawa konsekuensi baik terhadap siswa maupun warga sekolah yang bersangkutan. Penerapan Full Day School ini menuai pro dan kontra dari kalangan tenaga pendidik, orang tua, pakar pendidikan. Akan tetapi penerapan ini berdampak positif bagi siswa yaitu Penerapan ini menjanjikan perkembangan karakter dan prestasi belajar peserta didik saat ini. Hal tersebut dikarenakan kesempatan belajar siswa lebih banyak dan guru bebas menambah materi melebihi muatan kurikulum. (Islamika, 2011 : 98).

Menurut etimologi kata Full Day School berasal dari bahasa Inggris. Full mengandung arti penuh, dan Day artinya hari. Jika digabung, akan mengandung arti sehari penuh. Sedangkan School mempunyai arti sekolah (Salim Peter, 1988: 340). Jadi pengertian Full Day School adalah sekolah sepanjang hari atau proses belajar mengajar yang diberlakukan dari pagi hari sampai sore hari dengan berbagai kegiatan yang ada disekolah. Menurut (Moch, Ikromi 2005: 54) menyatakan bahwa adanya penerapan lima hari sekolah ini lama waktu pembelajaran tidak akan menjadi beban, karena sebagian waktunya digunakan untuk kegiatan informal disekolah. Dan pada sistem ini banyak pola dan metode dalam proses belajar dan mengajarnya dituntut lebih menarik, sistem pembelajarannya tidak top down atau monologis karena dengan metode seperti ini, maka yang terjadi guru mengajar dan murid diajar, guru mengetahui segalanya dan murid tidak mengetahui apa-apa, guru membacakan dan murid mendengarkan, atau konsep seperti itu. Menurut Wiwik Sulistyaningsih (2008: 61) menyatakan bahwa penerapan Full Day School memiliki banyak waktu luang bagi guru untuk merancang kegiatan pembelajaran tidak hanya fokus pada materi wajib tetapi menambahkan materi lain yang sesuai dengan realita kehidupan yang ada dimasyarakat. Serta disesuaikan dengan jurusan yang diambil oleh siswa. 
Persyaratan yang harus dipenuhi dalam menerapkan Full Day School ada 5 diantaranya: a. Kesiapan moral yang dimiliki guru untuk mengemban amanah yang diberikan pemerintah, dengan jiwa tulus untuk dalam mendidik siswa dan memiliki kemampuan untuk mengelola dan mengembangkan pembelajaran. b. Kurikulum dan program pembelajaran yang kreatif, efektif dan atraktif agar siswa dapat merasakan asyik dan nyaman menjalani setiap program ini tentu hal ini menantang siswa untuk terus berprestasi. c. Menumbuhkan nilai karakter yang dimiliki anak, sekolah harus didesain bagaimana caranya agar anak memandang bahwa sekolah itu menjadi kehidupan nyata dimana lingkungan belajar, komunitas belajar penuh dengan penerapan nilai dan norma yang baik dalam membentuk akhlak atau karakter siswa. d. Fasilitas yang memadai dalam menerapkan lima hari sekolah. e.Terjalinnya kerjasama yang baik antara sekolah dengan pihak orang tua untuk menciptakan pendidikan yang lebih maju.

Penerapan lima hari sekolah yang diterapkan oleh pemerintah tentu memiliki dampak positif dan negatif, menurut Jumraeni (2018: 7) menyatakan bahwa ada beberapa dampak positif dari penerapan ini yaitu:

1. Dapat meningkatkan kemampuan kognitif anak.

2. Dapat mengasah kemampuan keterampilan anak baik dalam bidang pembelajaran maupun interaksi bersama teman sebaya.

3. Orangtua tidak akan khawatir kualitas pendidikan dan kepribadian putraputrinya karena anak-anaknya di didik oleh tenanga kependidikan yang terlatih dan profesional.

Program kebijakan pemerintah yang baru ini tentunya memiliki dampak negatif yang diterima oleh siswa maupun orang tua antara lain yaitu:
1. Siswa kurang berinteraksi dengan orangtua dan lingkungan tempat tinggal.

2. Siswa terlalu lelah, waktu istirahat berkurang karena dihabiskan di sekolah.

3. Tingginya tingkat strees dimiliki siswa karena lamanya waktu belajar di sekolah. Kondisi psikis siswa tertekan karena merasa terpaksa mengikuti pertambahan jam pelajaran (Islami Arizka : 2016).

Berdasarkan penjelasan di atas, peneliti akan membuat hasil penelitian yang berjudul "Penerapan Full Day School di SMA Negeri 1 Singaraja (Latar Belakang Penerapan dan Pengaruhnya Terhadap Prestasi Belajar Sosiologi Kelas XI IIS".

Penelitian ini dapat dikaji dengan menggunakan beberapa teori yaitu:

(1) Kajian Full Day School. Penerapan Full Day School merupakan muatan yang ada dalam kurikulum dengan seluruh isi kehidupan anak seperti belajar, bermain, beribadah, makan serta aktifitas lainnya yang di rangkaikan melalui sistem pendidikan dan pengajaran yang lebih lama dibandingkan sekolah formal lainnya. Program kebijakan baru yang telah diterapkan oleh pemerintah ini selain bertujuan mengembangkan manajemen mutu pendidikan, yang paling utama dalam penerapan ini yaitu adanya upaya pembinaan akidah dan akhlak para siswa dan menanamkan nilai-nilai positif dalam membentuk karakter pada peserta didik. Tuntutan kurikulum 2013 dan program lima hari sekolah lebih menuntut siswa aktif dan memberikan keleluasaan pada siswa untuk mengeksplore segala hal yang tidak diketahui tetapi harus disesuaikan dengan materi pembelajaran.

(2) Kajian Prestasi Belajar. Prestasi belajar merupakan hasil yang di capai oleh siswa setelah ia melakukan kegiatan pembelajaran tertentu saat di sekolah. Setelah mengikuti proses pembelajaran yang diukur menggunakan instrumen tes yang relevan. Prestasi belajar ini konotasi 
nya pada hasil belajar atau penilaian terhadap peserta didik di setiap semester nya meningkat, stabil, atau menurun. Penilaian ini dilihat aspek kognitif, afektif dan psikomotorik yang dilakukan secara terencana dan sistematis. Karena penilaian ini sangat berpengaruh pada guru maupun peserta didik, pengaruhnya terhadap guru yaitu harus bisa membuat metode, model, media yang digunakan dalam menunjang proses pembelajaran dikelas yang dibuat menarik, kreatif dan mengacu siswa berpikir kritis saat pembelajaran berlangsung. Tujuan prestasi belajar menurut (Nur Padilla, 2017:50) menyatakan bahwa: Kemampuan penguasaan materi yang dimiliki siswa saat pembelajaran berlangsung, Kecakapan minat dan bakat yang ada pada siswa saat proses belajar, Mengetahui tingkat kecerdasan siswa melalui standar yang telah ditetapkan

\section{Metode Penelitian}

Penelitian ini menggunakan metode deskriptif kualitatif. pendekatan kualitatif ini bertujuan untuk mendeskripsikan masalah dan penyelesaian yang akan diteliti. Penelitian ini berfokus pada penerapan dan pengaruh Full Day School terhadap prestasi belajar sosiologi. . Pendekatan kualitatif ini diharapkan dapat menjawab uraian secara mendalam melalui tingkah laku, ucapan, tulisan yang dapat diamati melalui individu dengan individu, kelompok dengan kelompok dan masyarakat dalam konteks tertentu yang dikaji secara lebih komprehensif. Lokasi penelitian ini bertempat di Kota Singaraja, tepatnya di Sekolah Menengah Atas (SMA) Negeri 1 Singaraja. Jln. Pramuka No. 4 Singaraja.

Sumber data dalam penelitian yaitu melalui observasi, wawancara, studi dokumentasi, angket atau kuesioner. Penentuan informan dalam penelitian ini dilakukan dengan teknik purposive sampling secara terstruktur, dengan terlebih dahulu di tentukan informan kunci (Sugiono, 2010: 300). Dengan data tersebut penelitian ini termasuk ke dalam penelitian studi kasus.

\section{HASIL DAN PEMBAHASAN}

\section{Latar Belakang SMA Negeri 1 Singaraja}

Sejarah berdirinya Sekolah Menengah Atas (SMA) Negeri 1 Singaraja berdiri 1 November 1950 dan merupakan sekolah tertua di Bali yang sampai saat ini masih dipandang sebagai sekolah unggulan. Sejak tahun 1950 sekolah ini memiliki peran yang sangat sentral dalam mendidik para calon pemimpin baik di Provinsi Bali maupun di daerah lain. Sejak saat itu sudah memiliki daya saing yang cukup memadai jika dibandingkan dari sekolah negeri yang lain. Sekolah Menengah Atas (SMA) Negeri 1 Singaraja terletak di Jalan Pramuka No. 4 Singaraja, Kelurahan Banjar Bali, Kecamatan Buleleng, Kabupaten Buleleng, Provinsi Bali. Dengan luas tanah 10.114 m2. Letak geografi yakni disebelah utara permukiman warga, sebelah timur pasar anyar, sebelah barat pertokoan, sebelah selatan kantor polisi.

\section{Penerapan Full Day School di SMA Negeri 1 Singaraja}

Program Full Day School sendiri ialah sebuah sistem pembelajaran yang dilaksanakan dalam waktu sehari penuh. Semula penerapan Full Day School ini menuai perdebatan yang sangat hebat dikalangan pendidik, siswa, dan dikalangan orang tua baik di pihak pro maupun kontra dengan berbagai alasan. Bahkan penerapan ini dikhawatirkan sulit diterima oleh siswa karena dihadapkan harus sekolah hingga 8 jam yang memberatkan siswa maupun dari pihak orang tua, karena membuat orang tua tidak bisa berkumpul dengan anaknya seperti biasa. Berbeda halnya dengan orang tua yang seharian bekerja diluar tentunya tidak mempermasalahkan hal ini. Namun ada juga orang tua yang setuju dengan adanya penerapan Full Day School. Konsep yang digunakan dalam kebijakan yang baru ini dalam mengembangkan inovasi sistem pembelajaran lebih mengedepankan 
kreativitas dari tiga ranah yaitu Kognitif, Afektif, dan Psikomotorik.

Untuk menghindari adanya pro dan kontra seharusnya pemerintah sebelum mengambil kebijakan yang baru ini tentunya perlu dikomunikasikan terlebih dahulu dengan warga sekolah dan orang tua siswa, dimana dari hal tersebut diberikan sebuah angket yang harus diisi untuk mengetahui respon dari pihak sekolah maupun orang tua atas kebijakan pemerintah yang baru ini. Dari data tersebut menyatakan lebih dari 90\% menyatakan setuju dengan penerapan ini, maka dari itu langsung dimuat dalam kurikulum untuk menerapkan nya. Tentunya pihak Kepala Sekolah selalu mengevaluasi selama 1 tahun berjalan apakah masih bisa dilanjutkan penerapan ini atau ingin balik ke 6 hari sekolah. Dari tanggapan pihak sekolah menyanggupi untuk terus melaksanakan nya walaupun masih terjadi kendala-kendala yang masih bisa diatasi bersama. Selain itu penerapan ini harus memperhatikan segala hal kesiapan fasilitas, kesiapan komponen yang diperlukan sekolah serta kesiapan programprogram yang akan diterapkan. Penerapan kebijakan yang baru ini juga menuai pro dan kontra dari kalangan pendidik seperti Sekolah Menengah Atas (SMA) Negeri 1 Singaraja yang berada pada pihak Pro sedangkan SMA Negeri 2 Singaraja berpihak kontra.

Sekolah Menengah Atas (SMA) Negeri 1 Singaraja merupakan sekolah rujukan pertama di Buleleng yang menerapkannya. Serta Sekolah ini terdapat dipusat Kota dan siswa nya $90 \%$ berasal tidak jauh jarak nya dari sekolah, serta fasilitas yang dimiliki oleh sekolah sangat memadai untuk menerapkannya ( Sudana, 50 tahun). Tidak sejalan dengan Sekolah Menengah Atas (SMA) Negeri 2 Singaraja yang kontra terhadap Full Day School (Kartawan, 52 tahun) menyatakan Penerapan lima hari di Sekolah Menengah Atas (SMA) 2 Singaraja tidak dapat dilaksanakan karena melihat kesiapan yg harus dipenuhi oleh pihak sekolah. Serta dengan jadwal mengajar dari pagi hingga sore maka pihak guru pun merasa keberatan karena ia tidak hanya mengurusi siswa nya saja tetapi dirumah memiliki keluarga yang harus diperhatikan. Hal ini juga berdampak pada siswa jika diterapkan lima hari sekolah maka siswa akan berpotensi merasakan kebosanan jika di sekolah dari pagi hingga sore, jika pihak sekolah belum bisa membuat programprogram yang kreatif.

Penerapan lima hari sekolah di SMA Negeri 1 Singaraja ini telah didukung dengan berbagai fasilitas yang tersedia demi menunjang pembelajaran. Diawali dengan ruang perpustakaan yang dimiliki yaitu dengan menyediakan ruang baca buku secara manual dan digital. Dimana perpustakaan digital ini berupa perpustakaan maya dengan memfasilitasi siswa untuk mengupdate materi-materi pembelajaran maupun tuga-tugas kelompok, kunjungan dilakukan oleh guru maupun siswa saat jam istirahat. Pihak pengelola perpustakaan juga menyediakan buku di pojok-pojok baca. Bahkan disetiap kelas telah memiliki almari untuk menampung buku-buku yang telah tersedia. Penerapan ini juga membuat anak dituntut untuk baca buku setiap akan masuk pada jam pelajaran pertama.

Faktor penghambat dalam penerapan program pemerintah yang baru di Sekolah Menengah Atas (SMA) Negeri 1 Singaraja diantaranya adalah sarana dan prasarana dalam hal ini masih kurangnya ruang kelas sehingga proses pembelajaran masih belum sepenuhnya efektif. Penerapan ini tentunya juga memilki kelemahan yaitu banyaknya kegiatan pada program yang dirancang oleh pihak sekolah berkaitan dengan Full Day School yang membuat siswa menjadi mudah lelah dan bahkan jatuh sakit dikarenakan siswa belum bisa membagi waktu dan kemampuan tubuhnya. Menurut Arsyadana (Arsyadana, 2010:11) "adanya sekolah yang diperlakukannya dari pagi hingga sore hari, maka sekolah lebih leluasa dalam mengatur jadwal pembelajaran".

Program kebijakan pemerintah yang baru ini berupa Full Day School di SMA Negeri 1 Singaraja sudah tergolong berjalan dengan baik dari hasil pengamatan peneliti dan hasil kuesioner yang telah peneliti sebarkan ke responden mendapat respon 
yang positif dari hasil tersebut didapatkan $70 \%$ siswa menyetujui program-program yang berlangsung disekolah ini dengan segala kendala yang dihadapi selama penerapan ini. Penerapan ini juga berdampak positif bagi siswa, dimana ia ditantang lebih giat lagi dalam belajar nya untuk bisa berprestasi dan bersaing dengan temannya dan penerapan lima hari sekolah ini juga memberikan cara pikir siswa menjadi maju yaitu dengan cara bagaimana ia dapat membagi waktu yang ada selama disekolah dan dirumah dengan disiplin waktu yang ia miliki selama lima hari berlangsung agar bisa menjaga kondisi tubuhnya agar tidak sakit maupun drop.

\section{Pengaruh Full Day School terhadap Prestasi Belajar Sosiologi Siswa Kelas XI IIS}

Pengaruh Full Day School terhadap hasil belajar sosiologi siswa disajikan dalam proses pembelajaran sehari-hari disekolah, cara guru mengajar, dan keaktifan siswa dalam menerima pelajaran. Pengaruh penerapan ini tentunya ditunjang oleh persyaratan yang pemerintah canangkan yaitu fasilitas yang harus memadai, kesanggupan dari pihak guru,siswa, maupun orang tua untuk menerima program ini dilaksanakan karena tidak sembarang sekolah bisa menerapkan kebijakan ini. Pemerintah juga perlu mendukung program ini dengan cara memenuhi keperluan fasilitas yang kurang disekolah agar penerapan ini dapat berjalan dengan baik bahkan bisa berdampak positif bagi generasi penerus bangsa.

Pengaruh positif dengan adanya program kerja pemerintah yang baru ini membuat siswa menjadi lebih terpacu untuk aktif, kreatif, inovatif dan modern disegala mata pelajaran maupun ekstrakurikuler, tidak hanya siswa saja yang dituntut tetapi sebagai seorang guru pun harus lebih memiliki wawasan daripada siswanya. Karena tuntutan K13 diharuskan seorang guru dapat menjadi fasilitator, motivator bagi siswanya untuk lebih aktif. Peran guru sangat sentral dalam membimbing siswa untuk lebih berprestasi dan memiliki attitude terhadap orang lain. Pada dasarnya prestasi itu penting tetapi jika tidak memiliki tata krama terhadap guru maupun orang lain sama aja tidak ada nilainya, karena dalam pelaksanaannya dituntut guru dapat mengajarkan siswa bagaimana pembentukan nilai karakter yang harus tumbuh melalui kesadaran siswa melalui program-program yang dibuat oelh sekolah.

Pengaruh negatif dari adanya Full Day School menurut pengakuan salah satu siswi di SMA Negeri 1 Singaraja atas nama Dewa Ayu Padma Dewi (17) ia menyatakan bahwa penerapan ini sebenernya sudah berjalan dengan baik tetapi saya tidak bisa mengatur waktu yang ada, pola pembelajaran saya mulai berubah yang biasanya jam 7-9 malam sekarang menjadi jam 3-4 pagi karena saya memilih setelah pulang sekolah membantu orang tua, setelah itu saya gunakan untuk istirahat dan membuat tugas-tugas sekolah begitupula setiap harinya selama penerapan lima hari sekolah ini. Terkadang hari libur sabtu-minggu dimanfaatkan untuk membuat tugas-tugas kelompok yang diberikan oleh sekolah, walaupun ada wacana dari pemerintah bahwa tidak ada pekerjaan rumah selama penerapan program pemerintah yang baru ini mungkin sulit terhindarkan karena guru dituntut untuk memberikan nilai sesuai dengan data penilaian siswa jadi guru pun harus memberikan tugas kepada siswa nya. (hasil wawancara dengan siswa kelas XI IIS) Tetapi tugas yang diberikan dipermudah lagi dengan memberikan jangka waktu yang cukup panjang untuk batas pengumpulannya. Inilah program kebijakan pemerintah yang tentunya menimbulkan dampak positif maupun dampak negatif bagi siswa itu sendiri.

Pengaruh Full Day School terhadap prestasi belajar sosiologi siswa ini dapat dilihat dari proses pembelajaran seharihari disekolah, cara guru mengajar, dan keaktifan siswa dalam menerima pelajaran. Secara umum penerapan ini di Sekolah Menengah Atas (SMA) Negeri 1 Singaraja telah menunjang proses meningkatkan hasil belajar siswa dari sarana dan prasarana. Namun ketersedian sarana dan prasarana untuk menerapkan masih perlu perbaikan, 
pengembangan, penambahan untuk meningkatkan mutu pendidikan. Nilai akademik peserta didik merupakan suatu tolak ukur yang digunakan demi ketercapaian suatu pembelajaran yang dilihat melalui kuantitas. Walaupun tidak selamanya nilai akademik siswa menjadi patokan dalam melihat keberhasilan pembelajaran, melainkan harus melihat proses untuk mencapai sebuah nilai akademik. Nilai yang didapatkan oleh peserta didik melalui pre-test dan post-test yang diberikan oleh guru.

Sekolah Menengah Atas (SMA) Negeri 1 Singaraja merupakan sekolah yang dikenal akan prestasi yang mampu bersaing hingga ke kancah internasional baik diperoleh oleh pihak guru maupun siswa. Ibu Amanda menyatakan bahwa siswa Sekolah Menengah Atas (SMA) Negeri 1 Singaraja lebih mengutamakan prestasi ketimbang sekolah nya, karena ia lebih mengejar prestasi walaupun dengan resiko ia tidak bisa naik kelas karena tidak menempuh pembelajaran disekolah. Bahkan anak seperti itu yang sering dikirim sekolah ataupun mewakili program pemerintah ke luar negeri untuk belajar disana bahkan bisa beberapa tahun di luar negeri, setiap tahun memang ada programnya dari Sekolah mengirimkan setidaknya ada dua orang ke luar negeri bahkan dari pihak luar pun melakukan pertukaran pelajar untuk menimba ilmu di SMA Negeri 1 Singaraja. Siswa dari Jurusan bahasa pertukaran ke Jepang sedangkan siswa MIPA ke Eropa sedangkan siswa IPS jarang ada pertukaran pelajar, karena rata-rata yang ke sekolah untuk pertukaran anak MIPA.

Full Day School pengaruhnya dalam prestasi belajar sosiologi yaitu dalam proses pembelajaran harus dibuat menyenangkan dan tidak membosankan karena mata pelajaran sosiologi diberikan pada saat jam mengantuk, jadi sebagai guru harus mengajak siswa nya keluar kelas untuk bermain sambil belajar ataupun mencari data disekitar lingkungan sekolah disesuaikan dengan materi pembelajaran. Hal lain yang dilakukan yaitu dengan memanfaatkan teknologi yang ada di kelas yaitu proyektor untuk menampilkan video yang dapat memacu siswa nya untuk berpikir kritis. Dengan metode belajar sambil bermain siswa tidak akan jenuh berada disekolah bahkan mereka akan menikmati proses pembelajaran disekolah. Penerapan lima hari sekolah ini juga berdampak pada siswa yaitu tugas-tugas yang seharusnya dikerjakan dirumah, guru memberikan kemudahan agar dikerjakan disekolah selama pembelajaran berlangsung. Serta diskusi-diskusi yang guru terapkan dapat dilakukan dikelasmaupun luar kelas sesuai dengan materi yang dibahas.

Menentukan prestasi belajar anak harus meliputi dua hal yaitu Faktor dari dalam diri individu terdiri dari faktor fisiologis dan psikologis. Maksudnya dalam artian kemampuan anak tidak bisa dipandang sama rata satu dengan lain karena mereka berbeda. Maka dari itu prestasi belajar dapat tumbuh pada diri seseorang melalui fisik dan psikologi nya. Dalam hal ini ada siswa yang memiliki kemampuan diatas dibandingkan dengan teman-temannya yang setiap diberikan tugas maupun saat proses pembelajaran ia dapat mengikuti dengan baik. Tentunya hal ini didapat dari ia mengikuti berbagai program pendidikan yang orang tua tempuh melalui les ataupun dengan belajar secara mandiri karena hal ini tidak bisa ditempuh secara instan melainkan harus berproses. Terkadang prestasi belajar ini tumbuh melalui faktor dari dalam individu sendiri. Sedangkan bagi mereka yang memiliki kemampuan masih dibawah pasti memiliki beberapa faktor penyebab bisa karena ekonomi, keluarga, lingkungan hal tersebut sangat mempengaruhi individu untuk mengeluarkan kemampuan diri yang dimilikinya.

Prestasi belajar siswa tidak hanya dapat dilihat dari faktor dari dalam saja melainkan Faktor dari luar individu, yaitu Terdiri dari faktor lingkungan dan faktor instrumental. Hal ini yang dihadapi oleh siswa yaitu dengan adanya program kebijakan pemerintah yang baru. Banyak perubahan yang harus mereka adaptasi dan mereka terapkan dalam kesehariannya. 
Dimana program ini dapat dikatakan berdampak positif dan negatif bagi siswa. Tergantung juga dari siswa menanggapi perubahan ini tentunya banyak siswa yang tidak siap dengan penerapan ini dan banyak juga siswa yang menikmati perubahan ini. Penerapan Full Day School ini termasuk kedalam faktor dari luar individu yaitu faktor instrumental yang mempengaruhi prestasi belajar anak. Faktor instrumental berupa penggunaan kurikulum, guru, sarana dan fasilitas, administrasi, dan program kebijakan pemerintah yang tengah berlangsung hingga saat ini.

\section{Simpulan dan Saran Simpulan}

Berdasarkan hasil penelitian yang telah dipaparkan pada pembahasan di atas, maka peneliti dapat menarik beberapa kesimpulan bahwa: Penerapan Full Day School di SMA Negeri 1 Singaraja sudah berjalan dengan baik dari data yang didapat melalui wawancara dengan pihak sekolah dan siswa untuk menjawab permasalahan terkait penerapan lima hari sekolah di SMA Negeri 1, walaupun dalam penerapan nya masih terdapat kendala yang dihadapi baik dari guru,siswa maupun warga sekolah lainnya. Dengan adanya penerapan ini memberikan dampak bagi pihak sekolah dan orang tua, dimana orang tua lebih tenang saat meninggalkan anaknya untuk bekerja karena telah dikontrol anaknya disekolah. Tentu penerapan ini diharapkan dapat mengubah cara pandang anak didik agar dapat disiplin waktu baik dirumah maupun disekolah dan dapat menghindari hal-hal negatif saat tidak berada disekolah. Karena penerapan ini diharapkan dapat mengurangi angka kenakalan remaja di Buleleng saat ini. Dari hasil pengamatan peneliti dan hasil penyebaran kuesioner didapatkan bahwa penerapan lima hari sekolah ini mendapat respon yang positif dari pihak siswa bahwa siswa menyetujui penerapan ini dan memberikan manfaat bagi siswa itu sendiri.

Pengaruh Full Day School terhadap prestasi belajar sosiologi siswa kelas XI IIS yaitu siswa lebih terpacu dalam mengembangkan kemampuan yang dimiliki pada dirinya, saat pembelajaran berlangsung disekolah bahkan guru telah mempermudah siswa agar dapat menikmati penerapan kebijakan pemerintah ini dengan cara mengubah pola pembelajaran dan mengurangi tugas yang diberikan dirumah melainkan tugas tersebut harus diselesaikan disekolah. Serta jika ada tugas pasti dibberikan waktu yang cukup panjang untuk menyelesaikannya. Jika dilihat dari nilai sosiologi kelas XI IIS sudah mengalami peningkatan dan nilai nya tidak ada yang dibawah ketuntasan belajar minimal (KKM).

Pengaruh prestasi belajar anak tidak hanya dilihat dari faktor dari dalam saja melainkan faktor dari luar individu, yaitu terdiri dari faktor lingkungan dan faktor instrumental. Penerapan lima hari sekolah ini juga berpengaruh terhadap prestasi belajar anak dan pengaruh nya cukup signifikan Jadi prestasi belajar anak tidak hanya berpengaruh dari luar saja melainkan dari faktor dalam diri seseorang. Penerapan Full Day School ini dipengaruhi oleh faktor luar berupa faktor instrumental.

\section{Saran}

1. Penerapan lima hari sekolah ini tentunya dapat terus dievaluasi dan diberikan perhatian yang khusus bagi sekolah-sekolah yang telah menerapkan karena masih banyak yang tidak sesuai dengai syarat yang telah dibuat oleh pemerintah. Bahkan dari fasilitas dan persiapan dari siswa maupun sekolah perlu diperbaiki kedepannya.

2. Kepada Guru Sosiologi agar terus mengupdate atau pemperbaharui inovasi-inovasi yang digunakan untuk proses pembelajaran agar siswa tidak jenuh selama pembelajaran berlangsung karena jadwal yang cukup padat dari pagi hingga sore.

3. Pelajar harus mengetahui bahwa penerapan yang dibuat oleh pemerintah ini tentu membawa dampak yang positif bagi siswa, maka dari itu siswa harus terus mengevaluasi kekurangan yang dimiliki nya dan mengikuti proses pembelajaran dengan baik serta mengikuti penerapan lima hari sekolah 
ini dengan semaksimal mungkin agar prestasi belajar terutama dalam pelajaran sosiologi terus meningkat setiap semesternya.

\section{UCAPAN TERIMAKASIH}

Dalam penelitian ini, peneliti mengucapkan terima kasih kepada Rektor Undiksha, Bapak Dekan FHIS, Bapak Ketua Jurusan Sejarah, Sosiologi dan Perpustakaan, Bapak Kaprodi Pendidikan Sosiologi, Bapak Dr. I Wayan Mudana, M.Si selaku Dosen Pembimbing I, Ibu Dr. Luh Putu Sendratari, M.Hum selaku Dosen Pembimbing II, Ibu Dr. Tuty Mariyati, M.Pd, selaku Dosen Penguji, Kepala Sekolah SMA Negeri 1 Singaraja, Staf Guru, Staff Tata Usaha dan para peserta didik SMA Negeri 1 Singaraja kelas XI IIS yang telah bersedia memberikan data yang dibutuhkan, serta pihak-pihak yang tidak bisa disebutkan satu per satu yang telah memberikan bantuan dan kontribusi besar dalam penelitian skripsi ini.

\section{Daftar Pustaka}

Arikunto, Suharsimi. 2014. Prosedur Penelitian Suatu Pendekatan Praktik. Jakarta : Rineka Cipta.

Arsyadana, Addin. 2010. Penerapan Sistem Full Day School Sebagai Upaya untuk Meningkatkan Kualitas Pendidikan di MI Al-Qamar Nganjuk. Skripsi. Universitas Islam Negeri Maulana Malik Ibrahim.

Ghozali, Imam. 2011. "Aplikasi Analisis Multivariate Dengan Program SPSS". Semarang: Badan Penerbit Universitas Diponegoro

Ikromi, Moch. 2005. Pengembangan Manajemen Sistem Pendidikan, Tesis Universitas Islam Negeri (UIN) Malang, hal. 54

Islami, Arizka Min Nur. 2016. Implementasi Program Pendidikan Full Day School Di MI Muhammadiyah Karanglo Kecamatan Cilongok
Kabupaten Banyumas.Skripsi S1. Institut Agama Islam Negeri Purwokerto

Jumraeni. 2018. Dampak Sosial Implementasi Full Day School. Jurusan Sosiologi Fakultas IImu Sosial. Universitas Negeri Makassar Kecamatan Bajo Kabupaten Luwu

Salim, Peter. 1988. Advanced EnglishIndonesia Dictonary. Jakarta: Modern English Press, hal.340

Sugiyono. 2011. Metode Penelitian Kombinasi (Mix Methods). Bandung : Alfabeta hlm. 397

Supardi, US. 2013. Aplikasi Statistika Dalam Penelitian, Konsep Statistika yang Lebih Komprehensif. Jakarta. Change Publication

Sulistyaningsih, Wiwik. 2008. Full Day School \& Optimalisasi Perkembangan Anak, Yogyakarta: Paradigma Indonesia, hal. 61 